\title{
Calymmian and Tonian basement in the Chiapas Massif Complex, southern Mexico: Implications on Oaxaquia- Amazonia-Baltica connections within Rodinia
}

\author{
YULY TATIANA VALENCIA MORALES ${ }^{1}$, BODO \\ WEBER $^{1}$, M. DANIELA TAZZO-RANGEL ${ }^{1}$, RENEE \\ GONZÁLEZ-GUZMÁN ${ }^{2}$ AND DIRK FREI ${ }^{3}$
}

${ }^{1}$ Centro de Investigación Científica y de Educación Superior de Ensenada BC (CICESE)

${ }^{2}$ CICESE

${ }^{3}$ University of the Western Cape

Presenting Author: yvalencia@cicese.edu.mx

Deciphering the origin of small Precambrian basement inliers in the mainly Permian Chiapas Massif Complex (CMC) is crucial for a better understanding of southern Mexico's role within Rodinia. New U-Pb zircon ages (LA-ICPMS) and Sm-Nd isotope systematics (TIMS) from meta-igneous rocks of the newly defined Catarina Unit in the CMC are reported. The results provide evidence of a Paleo- to Early Mesoproterozoic crust that differs significantly from typical Precambrian basement (Oaxaquia, 1.25-0.99 Ga [1]) and the rest of the CMC [2]. The Catarina Unit is composed by banded felsic and mafic orthogneiss (amphibolite) with Calymmian magmatic protoliths yielding zircon crystallization ages between $\sim 1.55$ and $\sim 1.94 \mathrm{Ga}$, and $\mathrm{Sm}-\mathrm{Nd} \mathrm{T}_{\mathrm{DM}}$ model ages between 1.91 and $2.37 \mathrm{Ga}$ $\left(\varepsilon \mathrm{Nd}_{(1.5 \mathrm{Ga})}=-0.7\right.$ to +1.2$)$. Reworking of an older crustal component in granitic protoliths is further suggested by inherited zircon cores with ${ }^{207} \mathrm{~Pb} /{ }^{206} \mathrm{~Pb}$ apparent ages between $\sim 1.85$ and $\sim 1.70 \mathrm{Ga}$. Amphibolite of the Catarina Unit displays similar or only slightly more radiogenic $\varepsilon \mathrm{Nd}_{(1.5 \mathrm{Ga})}$ ranging from -0.5 to +2.9 , suggesting minor depleted mantle addition in this mafic protoliths. Zircon overgrowths document migmatization of the orthogneiss during a major Tonian thermotectonic event at $\sim 0.96$ Ga that led to the intrusion of granitoids (now biotite quartzfeldspathic gneisses) with crystallization ages between $969 \pm 17$ Ma and $978 \pm 18 \mathrm{Ma}$ and $\mathrm{T}_{\mathrm{DM}}$ of 2.0 to $1.8 \mathrm{Ga}$, further indicating crustal melting. Similar as elsewhere in the CMC, all rocks show metamorphic overprint during the Permian-Triassic. The new results are interpreted in terms of Calymmian active margin that probably established along the margin of Amazonia, where reworking of cratonic basement and the addition of new crustal material took place, forming the protoliths of the Catarina Unit. At a later stage, the juvenile Oaxaquia arc accreted to the cratonic margin. Following Amazonia and Baltica collision during the final stages of Rodinia assembly at $\sim 0.99 \mathrm{Ga}$, this part of the orogen entered in a period of uplift, gravitational collapse, and relaxation similar to the Dalane phase known from Baltica.

[1] Ortega-Gutiérrez et al. (2018), Earth Science Reviews 183, 2-37.

[2] Weber et al. (2018), Lithos 300-301, 177-199. 